\title{
An investigation on the effect of investor's behavior on fund management
}

\author{
Abolfazl Danaei ${ }^{a}$, Younos Vakil Alroaia ${ }^{b}$ and Majid Razinia ${ }^{c^{*}}$
}

${ }^{a}$ Department of Management, Semnan Branch, Islamic Azad university, Semnan, Iran.

${ }^{b}$ Department of Management, Semnan Branch, Islamic Azad university, Semnan, Iran.

${ }^{C}$ Department of Management, Science and Research Branch, Islamic Azad University, Semnan, Iran

\section{CH R O N I C L E}

Article history:

Received June 28, 2013

Received in revised format

19 October 2013

Accepted 20 December 2013

Available online

December 272013

Keywords:

Mutual fund

Investor behavior

Tehran Stock Exchange

\section{A B S T R A C T}

\begin{abstract}
There are many evidences to believe that investors' personal characteristics influence on their financial decisions when they purchase stocks, bounds, etc. In this paper, we present an empirical investigation to study the effects of 20 personal characteristics on 52 managers of mutual funds in Iran. Using Pearson correlation test, the study has detected that seven factors including anchoring \& adjustment, framing, over confidence, illusion of control, hindsight, recency and self-attribution positively influence on investors' behaviors. In addition, five factors including consistency, self-control, loss aversion, regret aversion and availability negatively influence on investors' behaviors. However, the study did not find any evidence to confirm any kind of relationship of representativeness, conservatism, ambiguity aversion, optimism, mental accounting, confirmation and status quo on investors' behaviors.
\end{abstract}

\section{Introduction}

There are many evidences to believe that investors' personal characteristics influence on their financial decisions when they purchase stocks, bounds, etc. (Nagy \& Obenberger, 1994; Thaler, 2005). In some evens, there are some extraordinary interest in investing on bounds and stock market called irrational exuberant (Shiller, 2005; Parisi \& Smith, 2005; Sultana, 2010). Some investors do not sell their poor performers on time and end up writing significant amount of loss despite the fact that financial data as well as technical charts give sell signals (Pompian, 2011). On the contrary, many fund managers sell some high flyers on early stage and reduce their profits, significantly. These are just simple evidences to believe that it is possible to do a good due diligence but make wrong investment decisions; buy/sell emotionally and end up having unpleasant consequences. Therefore, fund manager organizations need to select appropriate people when they hire fund managers and consider employees' personal characteristics along with other professional backgrounds.

*Corresponding author. Tel: +98-912-1316312

E-mail addresses: razi_majid@yahoo.com(M. Razinia) 
Xiao (2007) performed an empirical investigation on irrational exuberance and stock market valuations by looking into evidence from China. The study evaluated the fundamental efficiency of stock market valuations in China and reported stock valuations in China had deviated significantly from underlying firm-level fundamentals. Given the effect of the stock market for assigning investment funds in China, the results suggested that China's stock market development might generate an inefficient resource allocation and it could cause detrimental impacts on the real economy.

Goedhart et al. (2005) performed an investigation to find out whether fundamentals or emotions drive the stock market. They stated, "some behaviorists would even assert that stock markets lead lives of their own, detached from economic growth and business profitability". Hong et al. (2005) performed an investigation on the effects of word-of-mouth in the holdings and trades of money managers.

Leong et al. (2002) provided a comprehensive discussion of the psychological and behavioral investor perspectives responsible for the phenomenon of stock price momentum. Anchoring, overconfidence, herding, mental accounting, myopic loss aversion, regret aversion, prospect theory, over-reaction and under-reaction, representativeness, non-transitivity and question framing, hindsight bias and pride, barn-door closing, sensation seeking, and response to market consensus estimate were all investigated to offer description for the abnormal superior performance of value stocks over growth stocks. They applied empirical examination to describe that enough overconfident investors and financial analysts anchor on past EPS growth rates and systematically over-extrapolate to overestimate the EPS of growth stocks and under-estimate the EPS of value stocks. As stock value correction sets in over time horizon, value stocks would more likely outperform growth stocks. They also examined the effect of firm size and reported that large-cap investing could work better with the growth style strategy and that small-cap investing could work better with the value style strategy.

\section{The proposed study}

This paper presents an empirical investigation to study the effects of 20 personal characteristics on 52 managers of mutual funds in Iran. There are 20 characteristics associated with managers of mutual funds including anchoring \& adjustment, framing, over confidence, illusion of control, hindsight, recency, self-attribution, consistency, self-control, loss aversion, regret aversion and availability, representativeness, conservatism, ambiguity aversion, optimism, mental accounting, confirmation and status quo. The main hypothesis of this survey investigates whether there is any meaningful relationship between these 20 factors and investors' behavior. The survey designs a questionnaire in Likert scale and distributes it among 52 managers of some Iranian mutual funds over the period 20122013. Cronbach alpha was calculated as 0.76 , which is within an acceptable level and therefore, we can perform statistical test to find the relationship between two managers' personal characteristics and investment decisions. The study uses Kolmogorev-Smirnov test to for normality test and Table 1 summarizes the results of our survey.

Table 1

The summary of Kolmogorev-smirnov test

\begin{tabular}{|c|c|c|c|c|c|c|c|}
\hline \multirow[t]{2}{*}{ Number } & \multicolumn{2}{|c|}{ Normal parameters } & \multicolumn{3}{|c|}{ Maximum deviation } & \multirow[b]{2}{*}{$\mathrm{Z}$} & \multirow[b]{2}{*}{ P-value } \\
\hline & Mean & Std. dev. & Absolut & Positive & Negative & & \\
\hline 44 & 3.92 & 0.34 & 0.18 & 0.18 & -0.16 & 1.20 & 0.11 \\
\hline
\end{tabular}

The result of Table 1 demonstrates that all data are normally distributed and we can use Pearson correlation test to verify the hypotheses. 


\section{The results}

In this section, we present the effects of Managers' personal characteristics on investment behavior.

\subsection{The positive factors}

In our study, there were positive and meaningful relationship between seven factors including anchoring $\&$ adjustment $(r=0.44$, Sig. $=0.000)$, framing $(r=0.40$, Sig. $=0.000)$, over confidence $(r$ $=0.39$, Sig. $=0.000)$, illusion of control $(r=0.39$, Sig. $=0.000)$, hindsight $(r=0.34$, Sig. $=0.000)$, recency $(r=0.30$, Sig. $=0.000)$ and self-attribution $(r=0.30$, Sig. $=0.000)$ positively influence on investors' behaviors.

\subsection{The negative factors}

In addition, five factors including consistency $(\mathrm{r}=-0.30$, Sig. $=0.000)$, self-control $(\mathrm{r}=-0.31$, Sig. $=$ $0.000)$, loss aversion $(r=-0.36$, Sig. $=0.000)$, regret aversion $(r=-0.38$, Sig. $=0.000)$ and availability $(\mathrm{r}=-0.38$, Sig. $=0.000)$ negatively influence on investors' behaviors.

\subsection{Other factors}

The present study did not find any evidence to confirm any kind of relationship of representativeness, conservatism, ambiguity aversion, optimism, mental accounting, confirmation and status quo on investors' behaviors.

\section{Conclusion}

There is no doubt that investment decision making needs discipline and proper attitude, however, there are many evidences, which indicate people make their financial decision without considering facts and figures. Some investors do not sell their poor performers on time and end up writing significant amount of loss despite the fact that financial data as well as technical charts give sell signals. On the contrary, many fund managers sell some high flyers on early stage and reduce their profits, significantly. In this paper, we have presented an empirical investigation to study the effects of personal characteristics on their investment decisions. Using Pearson correlation test, the study has detected that seven factors including anchoring \& adjustment, framing, over confidence, illusion of control, hindsight, recency and self-attribution positively influence on investors' behaviors. In addition, five factors including consistency, self-control, loss aversion, regret aversion and availability negatively influence on investors' behaviors. However, the study did not find any evidence to confirm any kind of relationship of representativeness, conservatism, ambiguity aversion, optimism, mental accounting, confirmation and status quo on investors' behaviors. The results of this survey are somewhat consistent with findings of Leong et al. (2002).

\section{Acknowledgement}

The authors would like to thank the anonymous referees for their comments on earlier version of this paper, which helped us improve the quality of the paper. We are also delighted for the support of Islamic Azad University, Semnan Branch.

\section{References}

Goedhart, M., Koller, T., \& Wessels, D. (2005). Do fundamentals-or emotions-drive the stock market. McKinsey Quarterly, 2005. 
Hong, H., Kubik, J. D., \& Stein, J. C. (2005). Thy neighbor's portfolio: Word-of-mouth effects in the holdings and trades of money managers. The Journal of Finance, 60(6), 2801-2824.

Leong, C. T. C., Seiler, M. J., \& Lane, M. (2002). Explaining apparent stock market anomalies: Irrational exuberance or archetypal Human Psychology?. The Journal of Wealth Management, 4(4), 8-23.

Nagy, R. A., \& Obenberger, R. W. (1994). Factors influencing individual investor behavior. Financial Analysts Journal, 50(4), 63-68.

Parisi, F., \& Smith, V. L. (Eds.). (2005). The law and economics of irrational behavior. Stanford University Press.

Pompian, M. (2011). Behavioral Finance and Wealth Management: How to Build Optimal Portfolios that Account for Investor Biases (Vol. 667). Wiley. com.

Shiller, R. J. (2005). Irrational exuberance. Random House Digital, Inc.

Sultana, S. T. (2010). An empirical study of Indian individual investors' behavior. Global Journal of Finance and Management, 2(1), 19-33.

Thaler, R. H. (Ed.). (2005). Advances in behavioral finance (Vol. 2). Princeton University Press.

Xiao, F. (2007). Irrational exuberance and stock market valuations: evidence from China. Journal of Post Keynesian Economics, 29(2), 285-308. 